East African Journal of Science, Technology and Innovation, Vol. 2 (2): March 2021

This article is licensed under a Creative Commons license, Attribution 4.0 International (CC BY 4.0)

\title{
Constraints in Water Access in Laikipia County, Case of Ewaso Ng'iro River Basin in Kenya
}

\author{
1LESRIMA, S. S., 2NYAMASYO G. H.N., 3KARATU KIEMO, J. K.,
}

\begin{abstract}
${ }^{1 *}$ Wangari Maathai Institute for Peace and Environmental Studies, University of Nairobi, P.O. Box 30197-00100 Nairobi
${ }^{2}$ School of Biological Sciences, University of Nairobi, P.O. Box 30197-00100, Nairobi

${ }^{3}$ Department of Sociology and Social Work, University of Nairobi, P.O. Box 30197-00100 Nairobi

*Corresponding Author: simeonlesrima@gmail.com
\end{abstract}

\begin{abstract}
Challenges to water access are characterized by ineffective water institutions in Upper Ewaso $\mathrm{Ng}^{\prime}$ iro North River basin. The inability of policies to create trust and equity for sustainable water access is critical despite institutional reforms undertaken over the years. The impact of scarcity and limitations noted are more pronounced in upstream downstream landscape breeding a sense of dissatisfaction and perception of inequality among water users and stakeholders. Study adopted a mixed methods with data collection tools used were; desktop analysis, field visits and discussions, structured questionnaires, Key Informant Interviews and Focus Group Discussions. Interviews with 384 randomly selected households were conducted and data analyzed using descriptive statistics. Theory of Access informed the study. The findings showed that rivers and boreholes are the main water sources in the sub-basin. Consequences of unsatisfactory state of water access attributed to weak water governance policies and water management institutions. Lack of trust among water users remain latent easily triggered by scarcity and political-economic and social disruptions during severe droughts. Study's recommendations are development of effective communication mechanisms to share information, adherence to regulations and government to implement current and past reforms to mitigate constraints to water access.
\end{abstract}

Key Words: Water access, Water Governance, Institutional reforms, Upstream-downstream landscape, Upper Ewaso Nyiro River basin

Cite as: Lesrima et al., (2021). Constraints in Water Access in Laikipia County, Case of Ewaso Ng'iro River Basin in Kenya. East African Journal of Science, Technology and Innovation 2(2).

Received: 01/08/20

Accepted: 20/12/20

Published: 25/03/21

\section{Introduction}

Water resources remain challenged by water scarcity and the development of Sustainable Development Goals (SDGs) highlight this predicament more so on food security (FAO \& IWMI, 2018; Rahman, 2013; UNESCO, 2018). Water shortages will result in increasing competition, which will constrain agricultural production and affect the incomes and livelihood opportunities of many residents in rural and urban areas (Dinar \& Hogarth, 2015; Pandey, 2011; Shrestha, Roth, \& Joshi, 2018). Water access is a universal problem experienced in many parts of the world and especially access to freshwater which breeds contention due to increased competition and unsustainable water use by upstream and downstream water users (Oscar Kipchirchir, 2015; Petersen-Perlman, Veilleux, \& Wolf, 2017).

In sub- Saharan countries, water access is a constant obstacle despite the many institutional reforms undertaken in the water sector and its management (Angoua, Dongo, Templeton, Zinsstag, \& Bonfoh, 2018). From 1990- 2015 improved access to water resources has been made possible where households were more likely to have access to improved water sources than the previous decade (Armah et al., 2018). Kenya has undergone 
deep rooted reforms in the water sector beginning with the Water Policy of 1999 resulting to the Water Act, 2002. These reforms led to the establishment new institutions and regulatory systems with a clear separation of policy and regulation as well as water supply service delivery and water resource management mandates. Constitutionally, every Kenyan has a right to clean and safe water in adequate quantities regardless of their location (Government of Kenya GOK, 2010). However past interventions through sector management regulations, the water sector continues to face various limitations and challenges in ensuring access to water resources by all users (Armah et al., 2018; Government of Kenya GOK, 2010; Morris et al., 2011).

Substantial reforms in the water sector provide a pathway to good governance in accelerated services, higher performance and adherence to human rights standards in water supply and sanitation services delivery (Angoua et al., 2018; Leclert, Nzioki, \& Feuerstein, 2016). Sociocultural dynamics play a critical role in the mediation of water access issues and challenges impacting the communities (Armah et al., 2018; Notter et al., 2007; Tortajada, 2010). The water sector reform policy implications affect the efficacy of water institutions especially on management of water access by upstream and downstream users (Angoua et al., 2018; Leclert et al., 2016; Kipchirchir, 2015). Implementation of water reforms gives institutions mandated an opportunity to ensure equity in water resources access by communities on river basins (MacAllister et al., 2020; Munia et al., 2016; Poricha \& Dasgupta, 2011).

Kenya's water strategy plan lays mechanisms for the realization of universal access to water with $60 \%$ targeting national coverage and $25 \%$ focused on urban sewerage (Government of Kenya GOK, 2010). With an increasing Kenyan population, the demand for water becomes inevitable and is further challenged by the expansion of economic sector and agricultural sector impacting water resources access (Kenya National Bureau of Statistics (KNBS), 2019; Leclert et al., 2016; Olagunju et al., 2019). With a growing population and the devolution process taking place, water demands will increase thereby impacting on water resources access by users on all fronts (MacAllister et al., 2020;
McCord, Dell'Angelo, Gower, Caylor, \& Evans, 2017; Olagunju et al., 2019).

Interestingly, the water sector continues to face a myriad of challenges which involve lack of clear coordination mechanism with state's environment departments operating in silos, low access to improved water and sanitation services, weaknesses in water resources management and limitations in water harvesting and storage, against the sector targets and expectations of the water users and stakeholders (Armah et al., 2018; Dell'Angelo et al., 2016; Olagunju et al., 2019; Kipchirchir, 2015)

Impacts of scarcity noted at the national level is more pronounced in upstream downstream landscape propagating a sense of dissatisfaction and perception of inequality among water users and stakeholders (Aeschbacher, Liniger, \& Weingartner, 2005; Angoua et al., 2018; Kipchirchir, 2015; Tortajada, 2010). Institutions mandated to improve water access include; Water Resource Management Authority (WRMA), (amended to Water Management Authority (WMA), Water Act, 2016), Water Services Regulatory Board (WSRB) (Government of Kenya GOK, 2010; Kiteme, 2020). WMA is responsible for the allocation of water resources through a permit system and for implementing a catchment management strategy on use, protection and control of water resources within a catchment like Upper Ewaso $\mathrm{Ng}^{\prime}$ iro river basin (Government of Kenya GOK, 2010; Isaboke, 2015; Kirschke et al., 2019).

Water management systems in Ewaso $\mathrm{Ng}^{\prime}$ iro sub basin grapple with a rapidly increasing population, urbanization and the effects of climate change (Aeschbacher et al., 2005; Bond, 2014; Magal and Wambua, 2017). Land use changes by commercial farmers have become an impediment to water access which pastoralists perceive as their historical traditional space (Bond, 2014; Magal and Wambua, 2017). Factors such as limited knowledge, attitudes and practices through poor waste management, and catchment degradation constitutes hindrances in reducing availability of potable water in adequate quantities to the communities (Cloke et al., 1995; Dawson and Martin, 2015; Farrington and Farrington, 2005; Kirschke et al., 2019).

Water resources access in Ewaso $\mathrm{Ng}^{\prime}$ iro continues to face challenges where mandated 
institutions have duplicate mandates and the capacity for enforcement inadequate ( Kipchirchir, 2015; Sikor and Lund, 2009). Institutions in the river basin also contend with financial constraints thereby any water user who can facilitate their financial deficit is perceived to be having preferential treatment by those who are not able to (Isaboke, 2015; Olagunju et al., 2019).

Water policy reforms by government over decades underscore the urgency of improved water resources access, use and management however existence of water access constraints rage on. This paper aims to explicate water resources equity solutions for water users both upstream and downstream thereby promote peaceful coexistence by decelerating water access constraints.

Water access is not always rights-based, nor do rights always ensure access by all stakeholders (Ribot and Peluso, 2009; Shrestha et al., 2018). Despite existence of Water Government permit system for commercial exploitation of deep aquifers and a prohibition of commercial exploitation of shallow ones, rule breaking of both are tolerated and goes unchecked. This in hand serve the interests of elites and those who control the land, with over-abstraction and often perceived to lead to loss of public access to water (Gichuki, 2010; Government of Kenya GOK, 2010; Shrestha et al., 2018). However, the focus of the study was on peri-urban which imply that different economic and social factors of different population could result to different outcomes in terms of water resources access, use and management and related conflicts (Isaboke, 2015; Kirschke et al., 2019). Proponents' of Access Theory also highlights that economic, technological, social network and power influence the level of access to natural resources such water and the roles of upstream and downstream water users (Dell'Angelo et al., 2016; Olagunju et al., 2019; Ribot and Peluso, 2009). It furthers supports that the perceptions by water users upstream and downstream have huge impacts on mechanisms of ensuring equitable access to water resources (Olagunju et al., 2019; Ribot and Peluso, 2009).

The study revealed that amid increasing competition for water, people are using new sources and technologies, searching for negotiated solutions based on local norms and rights, and co-opting other water users through cooperation to create access opportunities and avoid conflicts that characterize use of natural resources (Shrestha et al., 2018). Similar attempts have been made in managing access to water resources in the Upper Ewaso Ngiro river sub-basin but the access situation has remained unsatisfactory and prone to conflicts (Armah et al., 2018; Oscar Kipchirchir, 2015). The unsatisfactory results further support the notion that upstream water users are allowed more access than downstream water users with downstream water users blaming the upstream waters for using technology to abstract more water as noted by the theory of access (Gichuki, 2010; Kirschke et al., 2019; Ribot and Peluso, 2009).

Studies conducted in coastal regions in Bangladesh on water access problem focus on ground water sources conducted on low-cost aquifer storage and recovery and implications for improving drinking water access for rural communities. Bangladesh illustrated that the demand for more ambitious information systems, which supports monitoring but also fit-for-purpose designs was important in resolving water resources access (Kirschke et al., 2019; Magal and Wambua, 2017; Tortajada, 2010). Upper Ewaso Ng'iro river sub-basin has information systems established by research institutions and Government through legislation, regulations, policies however perception of inequalities to water resources access persist (Magal and Wambua, 2017; Kipchirchir, 2015). The challenge witnessed is that information systems are not robust in capturing all the data and also sharing it with all water stakeholders to remove perceptions of inequalities in Ewaso $\mathrm{Ng}^{\prime}$ iro river basin (Kirschke et al., 2019; Magal and Wambua, 2017; Sikor and Lund, 2009).

Remedial actions such as water allocation as a planning tool to minimize water access constraints in the Upper Ewaso Ng'iro North Basin suggested through the use of GIS enabled software are vital in evaluating how different groups access water resources both upstream and downstream (Armah et al., 2018; Kipchirchir, 2015). This remedial action up scaled water demand leading to illegal water abstractions reducing water accessibility by users downstream thus unable to ensure equitable water access (Kiteme, 2020; Kiteme and Gikonyo, 2002). The study intended to shed light by analyzing the water management practices employed to for equitable water 
access by various governance instruments such as water institutions, water sector reforms, policy, regulations and laws.

The study analyzed water access, use and management through the lens of Theory of Access by (Ribot and Peluso, 2009) which highlights the role perceptions on access play. Several mechanisms help to understand water resources conflict caused by access to natural resources and how access to the same trigger conflict. Rights-based access mechanisms include permission to property ownership which give more opportunities to access water resources (Armah et al., 2018; Ribot and Peluso, 2009). The proponents of this argue that access to water resources is a clear factor shaping the conflict because it looks at the rights through land ownership (Cloke et al., 1995; Kombo and Ekisa, 2015; Kipchirchir, 2015). The theory is relevant because it fronts the argument to expand conceptualizations of access beyond rights-based approaches to consider "a larger array of institutions, social and politicaleconomic" which are important in management of water resources access (Baldwin et al., 2018; Berry, 1989; Leclert et al., 2016). The theory guided the study in assessing whether communities within the study area have equal rights in access, use and management of water resources or whether some users have more rights, which they exploit to the detriment of other water users either upstream or downstream (Armah et al., 2018; Magal and Wambua, 2017). This theory supports views gathered from focus group discussions where respondents had a perception that upstream users had more water resources access than downstream users creating a lot of mistrust highlighting the likelihood of water conflicts on issues of access by all users (MacAllister et al., 2020; Magal and Wambua, 2017; McCord et al., 2017; Poricha and Dasgupta, 2011).

Game theory on the other hand describes, strategic decision making in which people must cooperate to gain advantage since the loss of one is the net gain of the other in regard to water resources access (Faghih and Akhavian, 2019). This theory was relevant in analyzing the relationship between access to water, use and management since competition entails a focus on self-interest which explains the continued existence of water resources conflict despite the water reforms (Gichuki, 2010; Isaboke, 2015; Ross, 2019). Dinar and Hogarth, (2015), argues that both in its non-cooperative (NCGT) and cooperative (CGT) forms, game theory has been central in its contribution to the analysis of important aspects related to water resources management and specifically water resources access.

A gap therefore exists on the reason why there is evidenced reluctance to implement water resources access regulation exists (Kiteme, 2020; Kiteme et al., 2008). External authorities must respect the rule making rights of all the stakeholders, while a system must be developed and implemented by the community to monitor behavior of water users upstream and downstream (Berry, 1989; Ostrom, 2000; Tortajada, 2010). Disputes resolution must be done in a low cost manner and should be accessible to all the stakeholders so as to dissuade the notion of inequalities by the water users (Armah et al., 2018; Magal and Wambua, 2017; Kipchirchir, 2015). Also responsibility for managing the commons should be done in an interconnected manner from the lowest level to the highest level to enhance cohesion on water resources access (Farrington and Farrington, 2005; Leclert et al., 2016; Notter et al., 2007).

Further suggestions from previous studies view water allocation as a planning tool to minimize water use conflicts arising from water resources access in the Upper Ewaso Ng'iro North Basin through use of GIS enabled software where findings showed that highest demand for water was from farmers practicing irrigation farming upstream (Armah et al., 2018; CalderónContreras and White, 2020; Isaboke, 2015). Consequently, this uncontrolled water demand leads to illegal water abstractions reducing water accessibility by downstream water users nevertheless, the study does not establish the role of water management institutions and mechanism in ensuring equitable water access through the water reforms undertaken (Gichuki, 2010; Kirschke et al., 2019; Kiteme, 2020).

In addition, the study revealed that amid increasing competition for water, people are using new sources and technologies, by having negotiated solutions that are in support of local norms and rights, and mechanisms that support inclusivity of all water users through cooperation to create water resources access opportunities reducing the number of water conflicts (Armah et al., 2018; Shrestha et al., 2018). Similar attempts have made in managing access to water 
resources in the Upper Ewaso $\mathrm{Ng}^{\prime}$ iro river sub-basin but the access to water resources persists due to inadequate capacity by institutions in implementation of the water reforms and basic enforcement of water regulations (Isaboke, 2015; Kipchirchir, 2015).

Dell'Angelo et al., (2016) confirm the working of the rules nested at water project level is crucial in managing water access conflicts however points out a gap as to why same governance rules are defective with institutions like WRUA not adequately managing access. Munia et al., (2016) developed a framework to quantify the dependency of downstream water stress on upstream water supply and applied the framework to Trans-boundary river basins which would enhance water accessibility by all users however its impacts on water resources access management is yet to be analyzed.

Analysis on the impacts of upstream water users on downstream users found that 2.12 billion people in 336 sub-basin areas experience water stress level changes, which emanate from water resources access and its management (MacAllister et al., 2020; Shishaye and Asfaw, 2020). However there is no conclusive finding on whether upstream water users cause disruptions to downstream users except for short periods of the year where there is droughts or long spells of dry weather (Armah et al., 2018). There is a need for studies on impacts on water uses upstream on downstream users arising out of over abstraction of water depending on seasonal variability and how they affect water resources access by all the stakeholders. Further, there is need for more studies on the use of technologies in management o water resources access as is suggested by the theory of access and the reduction of water resources conflicts emanating from access (Ribot and Peluso, 2009).

\section{Materials and Methods}

\section{Study area}

The study area was Upper Ewaso Ng'iro North River Sub-Basin which is one of the five sub regions (Isiolo, Mandera, Marsabit, Nanyuki, Rumuruti) that form the greater Ewaso $\mathrm{Ng}^{\prime}$ iro North River Basin. The study area captured rivers from Naro Moru River to Timau River at foot zones of Mt. Kenya and River Moyok. The study area is unique in that it serves various counties illustrating its trans-boundary nature as a River basin.

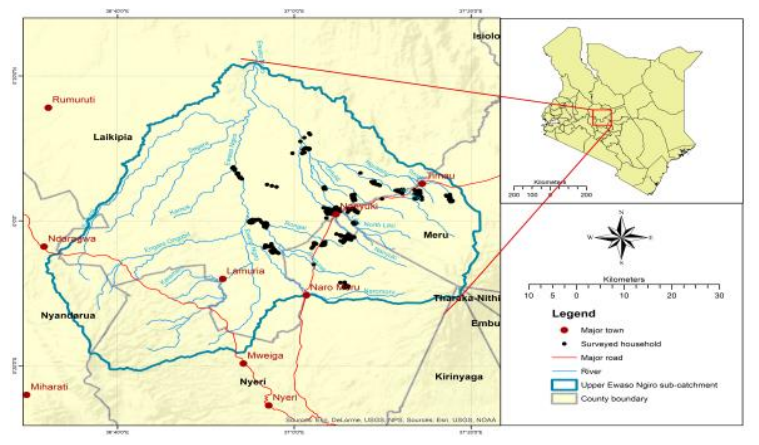

Figure 1: Map of the study area showing Surveyed areas highlighted using a mobile application

This study adopted descriptive survey research design which aimed at studying conditions or events that have already occurred and exist for this study. The design is also useful in describing the characteristics of a large population, making use of large samples and making the results statistically significant even when analyzing multiple variables. The design also allows many questions to be asked about a given topic giving considerable flexibility to the analysis.

The study utilized both primary and secondary data where primary data was collected through structured questionnaires, interviews, and focused group discussions and secondary data through desktop analysis. Key Informant Interviews (KII) relevant to technical and institutional, administrative and legislative information (Creswell and Creswell, 2018). Focus group discussions (FGDs) used to give additional information on accessibility to water and related conflicts (Mugenda \& Mugenda, 2008). Sampling formula used to ensure that there is equal representation of the target population with the sample size being 384 households (Mugenda and Mugenda, 2008; Williams, 2011). The target population were households within northwestern part of Mt. Kenya which covered adjacent Sub- Counties of Buuri in Meru County, Kieni of Nyeri County, Laikipia East and Laikipia North of Laikipia County. The process of data collection used mobile software K-Macho which was able to give GPS location of the study area (Apuke, 2017). Data analysis was computed using SPSS version 23 for descriptive statistics and summative content analysis for qualitative data analysis. 


\section{Results}

The results showed that livestock and agribusiness are key source of livelihoods with being employed and crop cultivation averaged as a source of livelihood. Results also showed that livelihoods depending on agri-business and livestock are water dependent therefore requiring access to more water resources (Figure 2).

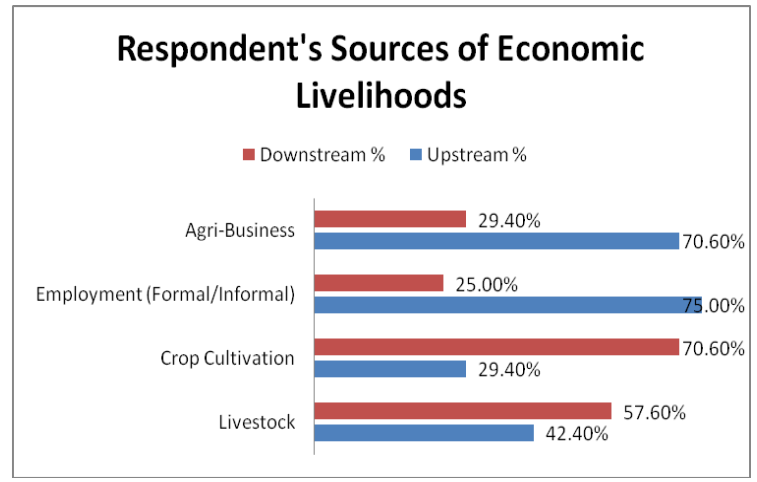

Figure 2: Households' economic source of Livelihood in Ewaso Ng'iro River Sub Basin

\section{Respondents' Perception on Water Users at the Water Access Points in Ewaso Ng'iro River Sub Basin}

Water users both in upstream and downstream perceive pastoralists to be the group that is accessing water the most with schools and urban centers having least access to water resources in Ewaso Ng'iro river basin as shown in Table 1.

Table 1: Groups perceived by respondents to access water resources at Upstream and Down Stream

\begin{tabular}{lll}
\hline $\begin{array}{l}\text { Groups perceived to } \\
\text { access water resources }\end{array}$ & $\begin{array}{l}\text { Downstre } \\
\mathrm{am}(\%)\end{array}$ & $\begin{array}{l}\text { Upstrea } \\
\mathrm{m}(\%)\end{array}$ \\
\hline $\begin{array}{l}\text { Pastoralists } \\
\text { Farmers upstream and } \\
\text { downstream }\end{array}$ & 43.7 & 46.9 \\
$\begin{array}{l}\text { Schools and urban } \\
\text { centers }\end{array}$ & 42.8 & 45.1 \\
Total & 13.5 & 8 \\
\hline
\end{tabular}

Institutions Managing Water resources Access in Ewaso Ng'iro River Sub Basin

The findings presented in Figure 4 shows some of the consequences as result of poor access to water resources within the study area. The findings pointed out $53.1 \%$ of the respondents indicated increased hatred and lack of trust
Majority of the respondents access their water from tapped water with upstream water users being most prevalent unlike the down steam water users who use the river as their water resources access point (Figure 3).

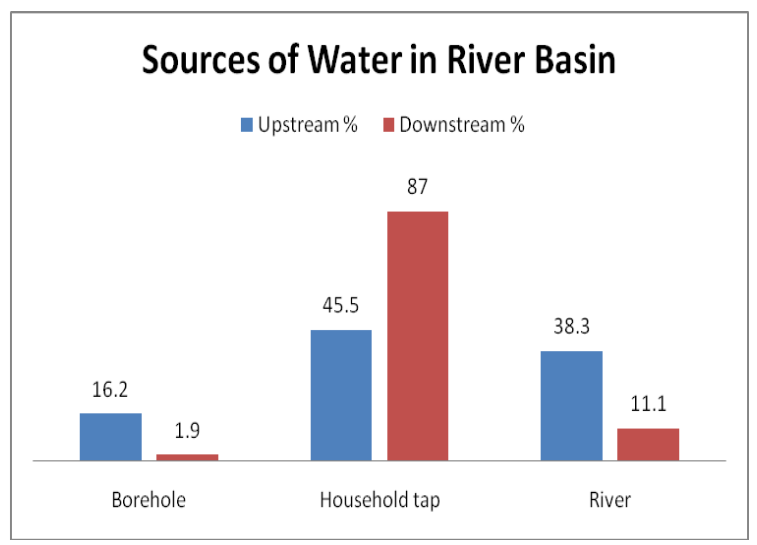

Figure 3: Water Access points from their Sources in Ewaso Ng'iro River Basin

Institutions managing water access in Ewaso $\mathrm{Ng}^{\prime}$ iro River Sub Basin indicate Nanyuki Water Sewerage and Sanitation Company (NAWASCO) as the main institution followed by water project committees with WRUAs having minimal management of water resources access. These institutions are supported by the water sector reforms and Water Act of 2016 in management of water resources (Table 2).

Table 2: Water resources Access Management by Institutions in Ewaso Ng'iro River Sub Basin

\begin{tabular}{lcc}
\hline Water Resources & & \\
Access & $\begin{array}{c}\text { Downstream } \\
\text { Management }\end{array}$ & $\begin{array}{c}\text { Upstream } \\
(\%)\end{array}$ \\
\hline WRUA Officials & 13.1 & 14.2 \\
Community & 24.3 & 2.5 \\
NAWASCO & 19.9 & 60.5 \\
Project & & \\
Committee & 42.7 & 22.8 \\
\hline
\end{tabular}

between groups and forced migration as the major consequences of poor access to water resources in Ewaso $\mathrm{Ng}^{\prime}$ iro river basin. 


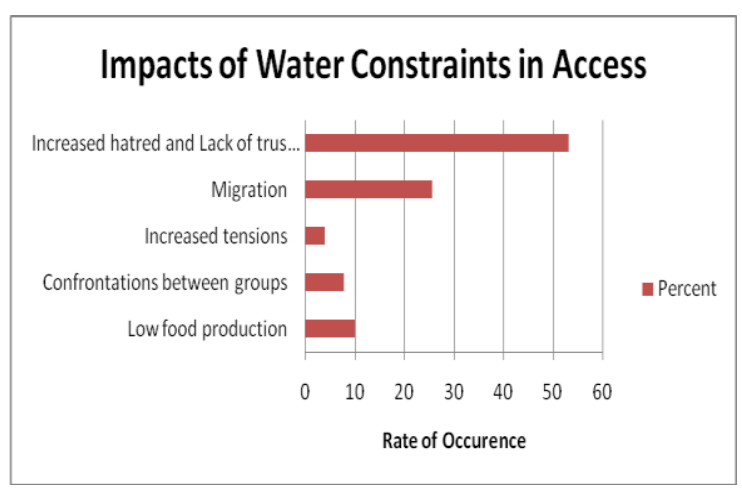

Figure 4: Impacts of inadequate Water Access Management in Ewaso Ng'iro River Sub Basin

The impacts of inadequate water access management results in increased mistrust among upstream and downstream waters users and also increased migration due to water conflicts in the river basin. Increased hatred and lack of trust were significant for both upstream and downstream water users as consequences of unequal water resources access in the river basin.

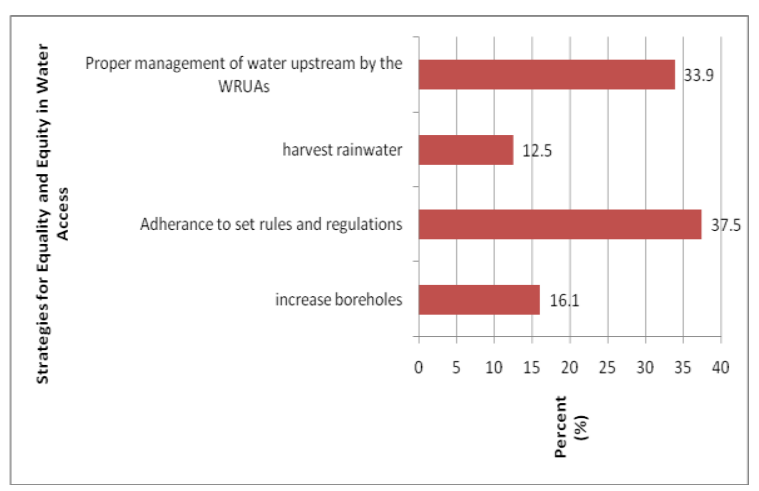

Figure 5: Water Access Strategies for Equality and Equity in Ewaso Ng'iro River Sub Basin

Majority of the respondents agree that adherence to rules and regulations as good strategy in enhancing water access management while proper management of water resources by upstream water users could focus on increasing equal water access by also the downstream water users.

\section{Discussion}

The unequal access to water resources among various water users in the Upper Ewaso $\mathrm{Ng}^{\prime}$ iro River North sub-basin was notably high as supported by the data (Magal and Wambua, 2017). Results indicate majority of the respondents access water through household tap water, followed by rivers and borehole as access points to water resources in Ewaso $\mathrm{Ng}^{\prime}$ iro river basin (Kiteme, 2020). The findings indicate that a significant proportion of respondents relied on water from rivers with majority of them residing downstream which points to underdevelopment of borehole and ground water use in the sub-basin (Kiteme, 2020; Kipchirchir, 2015). Although the implication of water use and management practices of people upstream affects the amount of water available for people downstream the study concurs with (Kiteme, 2020), that this impact is not necessarily the only cause of downstream shortages at water access points.

The blame game on who draws water more among the upstream and downstream water user groups is not proven but perceptions tend to create a sense of inequality and room for contestations as mentioned by other scholars in the river basin (Lanari et al., 2018; Olagunju et al., 2019). Pastoralists who live down stream and agricultural farmers upstream perceive pastoralists migration during dry seasons in search for pasture and water resources is the source of inter-ethnic conflicts at water access points as noted by (Leclert et al., 2016; Szaboova, Brown, and Fisher, 2020; Warurii, 2013). The contention lies with the perception by the respondent that those with tapped water have more privileged water access unlike those who have water access at the river source (Armah et al., 2018; Leclert et al., 2016; Kipchirchir, 2015).

This study also established perception since data on availability of water quantities were beyond the scope of this paper that highest consumers of water were large-scale horticultural farmers and pastoralists whose access to water resources breeds discontentment and rivalry between small-scale farmers downstream. Other studies however suggest higher consumption by horticultural farmer groups upstream leads to discontentment and possible triggers to water resources conflicts (Baldwin et al., 2018; Kiteme et al., 2008; Kipchirchir, 2015). It is further noted that households in majority of river basins have unsustainable access to improved water due to the financial, hydro-technical, institutional and organizational incapacities coupled with the low financial abilities of low-income earning households to continuously purchase water for domestic activities (Armah et al., 2018; Magal and Wambua, 2017; Myers and Hansen, 2020; Ribot and Peluso, 2009). This is illustrated by data of the number of households accessing 
water resources with those with tapped water found upstream and rivers downstream as majority (Kiteme, 2020; Myers and Hansen, 2020).

The low level of adoption of water harvesting strategies continues to affect water access despite the national strategy plan (Government of Kenya GOK, 2010; Magal and Wambua, 2017). Key informants interviewed claim that appointments of such new semi-autonomous government agencies are set-aside to reward political supporters most of whom have neither the passion nor the requisite preparation to implement the identified sector reforms (Calderón-Contreras and White, 2020; Poricha and Dasgupta, 2011; Sikor and Lund, 2009; Svarstad et al., 2018).

The study findings implied that unequal access to water has negative consequences on households within the areas with mistrust among water users seen as the main contribution to unequal access to water resources (Magal and Wambua, 2017; Schlager and Ostrom, 1992; Sikor and Lund, 2009). The finding indicates lack awareness on water governance policies as an obstacle in ensuring equity in water access (Munia et al., 2016; Kipchirchir, 2015).

For the downstream water users, ineffective water policies and lack of awareness were mentioned as causes of hindrances to water access with the upstream users indicating irregular rainfall seasons for the same (Angoua et al., 2018; Kiteme, 2020; van Rijswick, et al., 2014).

(Magal and Wambua, 2017) cites that lack of trust between various water users on who consume largest water in the basin also breeds contention. This study suggests that communicating information to stake holders on water availability, as a management tool on water sharing to reduce conflict over perception on inequality on water access. This proposition is shared by (Kiteme, 2020) who recommend use of information platform system in their research on water management in Upper Ewaso Ng'iro River Basin.

The results from key informants' interviews and focus group discussions attributed political interference to ineffectiveness of institutions mandated to manage water resources was established as a cause of water resources inequalities in terms of water access management by institutions (Armah et al., 2018; Kipchirchir, 2015; Tortajada, 2010).

The inability by institutions to enforce and ensure adherence to regulations perpetuates inequality in water access in the river basin (Kombo and Ekisa, 2015; Lanari et al., 2018; Tortajada, 2010). The capacity of water sector institutions will enhance the management of water resources access with reduction of duplicate mandates which renders them ineffective and better use of resources to implement policies thus reducing duplicity (Morris et al., 2011; Notter et al., 2007; Oscar Kipchirchir, 2015). This study agrees with Access Theory on the perceptions held by the upstream and downstream water users (Farrington and Farrington, 2005; Ribot and Peluso, 2009; Sikor and Lund, 2009) but with limited application for institutions such as WRUAs where the gap in implementing regulations continues to enhance the constraints to water access.

\section{Conclusion and Recommendations}

The study concludes that water access is constraint by inequality in water access, which is perceived to affect vulnerable downstream water users. The poor management of water upstream enhances water access inequalities for the downstream water users. The inadequate enforcement and adherence to water regulations and policies by institutions continues to upscale water access inequalities for both upstream and downstream users. The capacities of water institutions require more financial support for their operation and enforcement of water sector reforms in the Ewaso $\mathrm{Ng}^{\prime}$ iro river basin.

Development of effective communication mechanisms to ensure all water users share data and information regarding the state of water resource to eliminate potential unfounded perceptions of inequalities in accessing water. Creation of water abstraction policies as an additional policy and create institutions such as the Basin Catchment Protection Committees Enhance rainwater harvesting and upscale conservation agriculture to slow down run-off and increase yields while maximize availability of water to residents downstream. Fortify the use of new technologies such as roof catchment and runoff water systems 


\section{Acknowledgments}

I would like to acknowledge support and guidance from Prof. Gideon Nyamasyo, Dr. Kiemo Karatu as my supervisors, and Dr. Bessy Kathambi for her expertise in water related issues and conflict management and the entire department of WRUAs in Laikipia County, CENTRAD and my family members for their support. The authors declare no potential conflicts of interest concerning the research, authorship or publication of this article. The research described in this paper received no specific grant from any funding agency.

\section{References}

Aeschbacher, J., Liniger, H., \& Weingartner, R. (2005). River Water Shortage in a Highland-Lowland System: A Case Study of the Impacts of Water Abstraction in the Mount Kenya

Region. Mountain Research and Development, 25, 155-162.

Angoua, E. L. E., Dongo, K., Templeton, M. R., Zinsstag, J., \& Bonfoh, B. (2018). Barriers to access improved water and sanitation in poor peri-urban settlements of Abidjan, Côte d'Ivoire. PLOS ONE, 13, e0202928.

Apuke, O. D. (2017). Quantitative Research Methods: A Synopsis Approach. Kuwait Chapter of Arabian Journal of Business and Management Review, 6, 40-47.

Armah, F. A., Ekumah, B., Yawson, D. O., Odoi, J. O., Afitiri, A.-R., \& Nyieku, F. E. (2018). Access to improved water and sanitation in sub-Saharan Africa in a quarter century. Heliyon, 4, e00931.

Baldwin, E., McCord, P., Dell'Angelo, J., \& Evans, T. (2018). Collective action in a polycentric water governance system. Environmental Policy and Governance, 28, 212-222

Berry, S. (1989). Social institutions and access to resources. Africa, 59, 41-55.

Bond, J. (2014). A holistic approach to natural resource conflict: The case of Laikipia County, Kenya. Journal of Rural Studies, 34, 117-127.

Calderón-Contreras, R., \& White, C. S. (2020). Access as the Means for Understanding Social-Ecological Resilience: Bridging Analytical Frameworks. Society $\mathcal{E}$ Natural Resources, 33, 205-223.

Cloke, P., Goodwin, M., Milbourne, P., \& Thomas, C. (1995). Deprivation, poverty and marginalization in rural lifestyles in England and Wales. Journal of Rural Studies, 11, 351-365.

Creswell, J. W., \& Creswell, J. D. (2018). Research design: Qualitative, quantitative, and mixed method approaches. (18th ed.). Los Angelos: Sage.

Dawson, N., \& Martin, A. (2015). Assessing the contribution of ecosystem services to human wellbeing: A disaggregated study in western Rwanda. Ecological Economics, 117, 62-72.

Dell'Angelo, J., McCord, P. F., Gower, D., Carpenter, S., Caylor, K. K., \& Evans, T. P. (2016). Community Water Governance on Mount Kenya: An Assessment Based on Ostrom's Design Principles of Natural Resource Management. Mountain Research and Development, 36, 102-115.

Dinar, A., \& Hogarth, M. (2015). Game Theory and Water Resources Critical Review of its Contributions, Progress and Remaining Challenges. Foundations and Trends $®$ in Microeconomics, 11, 1-139.

Faghih, A., \& Akhavian, R. (2019). A GameTheory Approach to Construction Dispute Resolution through Mediation. Journal of Legal Affairs and Dispute Resolution in Engineering and Construction, 11, 05019004.

FAO, \& IWMI. (2018). More people, more food, worse water? A global review of water pollution from agriculture. Rome: FAO/IWMI.

Farrington, J., \& Farrington, C. (2005). Rural accessibility, social inclusion and social justice: Towards conceptualisation. Journal of Transport Geography, 13, 1-12.

Gichuki, F. N. (2010). Water Scarcity and Conflicts:A Case Study of the Upper Ewaso Ng'iro North Basin.

Government of Kenya GOK. (2010). Constitution of Kenya. Government of Kenya.

Isaboke, E. M. (2015). Influence of water resource users association leadership competencies on water resources management: a case of mount Kenya region (University of Nairobi). University of Nairobi, Nairobi.

Kenya National Bureau of Statistics (KNBS). (2019). Population and house results. Kenya: Kenya Bureau of Statistics KNBS.

Kirschke, S., Franke, C., Newig, J., \& Borchardt, D. (2019). Clusters of water governance problems and their effects on policy 
delivery. Policy and Society, 38, 255-277.

Kiteme, B. P. (2020). Hotspots of Water Scarcity and Conflicts in the Ewaso Ng'iro North Basin: Identifying context-specific water development priorities through an innovative and participatory approach. Nanyuki: Centre for Training and Integrated Research in ASAL Development (CETRAD).

Kiteme, B. P., \& Gikonyo, J. (2002). Preventing and Resolving Water Use Conflictsin the Mount Kenya Highland-Lowland Systemthrough Water Users' Associations. Mountain Research and Development, 22, 332-337.

Kiteme, B. P., Liniger, H., Notter, B., Wiesmann, U., \& Kohler, T. (2008). Dimensions of Global Change in African Moun-tains: The Example of Mount Kenya. Retrieved from http://re.indiaenvironmentportal.org.i n/files/Dimensions.pdf

Kombo, N., \& Ekisa, G. (2015). The Impacts of Land Use Changes on Livelihood of the Maasai Community in Kajiado County, Kenya. Ethiopian Journal of Environmental Studies and Management, 8, 433.

Lanari, N., Schuler, R., Kohler, T., \& Liniger, H. (2018). The Impact of Commercial Horticulture on River Water Resources in the Upper Ewaso Ng' iro River Basin, Kenya. Mountain Research and Development, 38, 114-124.

Leclert, L., Nzioki, R. M., \& Feuerstein, L. (2016). Addressing Governance and Management Challenges in Small Water Supply Systems - The Integrity Management Approach in Kenya. Aquatic Procedia, 6, 39-50.

MacAllister, D. J., MacDonald, A. M., Kebede, S., Godfrey, S., \& Calow, R. (2020). Comparative performance of rural water supplies during drought. Nature Communications, 11, 1099.

Magal, R. P., \& Wambua, B. N. (2017). Risk Assessment of the Coping and Adaptation Mechanisms for Pastoralists to Climate Change and Variability: A Case Study of Kongelai Ward, West Pokot County, Kenya. Asian Journal of Agriculture and Food Sciences, 5. https://doi.org/10.24203/ajafs.v5i2.473 2

McCord, P., Dell'Angelo, J., Gower, D., Caylor, K. K., \& Evans, T. (2017). Householdlevel heterogeneity of water resources within common-pool resource systems.
Ecology and Society, 22, art48.

Morris, J., O'Brien, E., Ambrose-Oji, B., Lawrence, A., Carter, C., \& Peace, A. (2011). Access for all? Barriers to accessing woodlands and forests in Britain. Local Environment, 16, 375-396.

Mugenda, M. O., \& Mugenda, G. A. (2008). Social Science Research: Theory and Principles. Nairobi, Kenya: Acts Press.

Munia, H., Guillaume, J. H. A., Mirumachi, N., Porkka, M., Wada, Y., \& Kummu, M. (2016). Water stress in global transboundary river basins: Significance of upstream water use on downstream stress. Environmental Research Letters, 11, 014002.

Myers, R., \& Hansen, C. P. (2020). Revisiting A Theory of Access: A review. Society $\mathcal{E}$ Natural Resources, 33, 146-166.

Notter, B., MacMillan, L., Viviroli, D., Weingartner, R., \& Liniger, H.-P. (2007). Impacts of environmental change on water resources in the Mt. Kenya region. Journal of Hydrology, 343, 266278.

Olagunju, A., Thondhlana, G., Chilima, J. S., Sène-Harper, A., Compaoré, W. R. N., \& Ohiozebau, E. (2019). Water governance research in Africa: Progress, challenges and an agenda for research and action. Water International, $44,382-407$.

Oscar Kipchirchir, K. (2015). Water Stress Tolerance of Six Rangeland Grasses in the Kenyan Semi-arid Rangelands. American Journal of Agriculture and Forestry, 3, 222.

Ostrom, E. (2000). Collective Action and the Evolution of Social Norms. Journal of Economic Perspectives, 14, 137-158.

Pandey, P. (2011). Understanding Patterns of Water Conflicts: Social and Political Variables. South Asian Survey, 18, 157171.

Petersen-Perlman, J. D., Veilleux, J. C., \& Wolf, A. T. (2017). International water conflict and cooperation: Challenges and opportunities. Water International, 42, 105-120.

Poricha, B., \& Dasgupta, B. (2011, December 5). Equity and access: Community based water management in urban poor communities: an Indian case study. 275-285. Las Vegas, USA.

Rahman, M. A. (2013). Water Security: Ethiopia-Egypt Transboundary Challenges over the Nile River Basin. 
Journal of Asian and African Studies, 48, 35-46.

Ribot, J. C., \& Peluso, N. L. (2009). A Theory of Access*. Rural Sociology, 68, 153-181.

Ross, D. (2019). Game Theory (Winter 2019). USA: Metaphysics Research Lab, Stanford University.

Schlager, E., \& Ostrom, E. (1992). PropertyRights Regimes and Natural Resources: A Conceptual Analysis. Land Economics, $68,249$.

Shishaye, H. A., \& Asfaw, A. T. (2020). Analysis and evaluation of the spatial and temporal variabilities of river water quality parameters. Applied Water Science, 10, 141.

Shrestha, A., Roth, D., \& Joshi, D. (2018). Flows of change: Dynamic water rights and water access in peri-urban Kathmandu. Ecology and Society, 23, art42.

Sikor, T., \& Lund, C. (2009). Access and Property: A Question of Power and Authority. Development and Change, 40, 1-22.

Svarstad, H., Benjaminsen, T. A., \& Overå, R. (2018). Power theories in political ecology. Journal of Political Ecology, 25, 350.

Szaboova, L., Brown, K., \& Fisher, J. A. (2020).
Access to Ecosystem Benefits: More than Proximity. Society \& Natural Resources, 33, 244-260.

Tortajada, C. (2010). Water Governance: Some Critical Issues. International Journal of Water Resources Development, 26, 297307.

UNESCO. (2018). The United Nations World Water Development Report 2018: Naturebased Solutions. Paris: UNESCO.

van Rijswick, M., Edelenbos, J., Hellegers, P., Kok, M., \& Kuks, S. (2014). Ten building blocks for sustainable water governance: An integrated method to assess the governance of water. Water International, 39, 725-742.

Warurii, F. K. (2013). Inter-ethnic conflicts: trends, causes, effects and interventions in Rumuruti division of Laikipia county, Kenya (1963 -2010) (Kenyatta University). Kenyatta University, Nairobi, Kenya.

Williams, C. (2011). Research Methods. Journal of Business \& Economics Research (JBER), 5. https://doi.org/10.19030/jber.v5i3.253 2 